\title{
LANGUAGE KINSHIP BETWEEN KOMERING VARIATION AND LAMPUNG MENGGALA
}

\section{Sudirman AM.}

FKIP-Universitas Muhammadiyah Metro, Lampung, Indonesia

Sudirmanaminin110@yahoo.com

${ }^{2}$ Dedy Subandowo

FKIP-Universitas Muhammadiyah Metro Lampung, Indonesia,

Dedy.subandowo@ummetro.c.id

\section{Ichsan Dacholfany}

PPS Manajemen Pendidikan- Universitas Muhammadiyah Metro Lampung, Indonesia, mihsandacholfany@yahoo.com

\begin{abstract}
ABSTRAK
Artikel ini mengkaji kekerabatan Isolek Komering dan Lampung Menggala kedua isolek tersebut, secara kualitatif ditandai perbedaan dalam persamaan atau persamaan dalam perbedaan tuturan 'mutually intelligble' antarpenutur bahasa yang diperlihatkan oleh evidensi unsur bunyi [u] [eu] pada ultima terbuka leksikon, pada kata [batu] [batteu]; evidensi unsur bunyi [nt] [tt] (homorgan geminasi) pada posisi antar-vokal pada leksikon [bintan] [bittan]; evidensi unsur pinjaman pada kata bermakna 'baru', 'pasir' menjadi inovasi [baReu] dan [pasiR]; dan secara diakronis telah terjadi inovasi [ampay] $\sim$ [ompay]'baru' dan [həni] $\sim$ [honi] 'pasir'. Sedangkan secara kuantitatif hasil kajian komparatif 200 kosa-kata Swadesh status isolek Komering dan bahasa Lampung merupakan bahasa kekerabatan 'language of family', kriteria Dialektometri, evidensi di atas merupakan perbedaan dialek dalam kelompok bahasa Lampung, karena hasil persentasi Isolek Komering-Menggala $82,16 \%$, disokong oleh Crowley, bahwa hubungan tersebut, termasuk hubungan antar-dialek dalam satu bahasa.
\end{abstract}

Kata Kunci: Bahasa; komparatif; instrumen; kriteria; dan isolek Komering

\section{INTRODUCTION}

The Lampung-Komering language study is one of the local languages that need to be discussed because the extinction of local languages in the world is enough to be a concern of UNESCO. As stated by Azhar, I. N., (2011), that at the meeting at UNESCO 2003 has been discussed about the program of saving the languages that are endangered. This statement is evident, that the issue of local languages has become the responsibility of the international world. As for indicators of the extinction of language, caused by speaker's factor, social condition factor, the internal factor of language, and policy factor, so the need to rescue the local language would be solution without lagging global competitiveness, as the Japanese and China, develop as the 
characteristic a community that is known by the international community. The international community recognizes that the heritage of the local language (region) of a nation must be saved, because of essential loss of a language in any world; it also means the disappearance of the cultural heritage of a community in the local community. Therefore, the concern of this study is Komering variation in Lampung language.

Toward two centuries, the Lampung language has been introduced to the academic world through the work of Van der Tuuk (1868-1872). Voorhoeve (1955: 21) explains that early studies on Lampung language have been conducted by Van der Tuuk in the Netherlands. At that time the collection of a text of Lampung Van der Tuuk which was published was brought by Governor General Sloet van de Beele back to Indonesia. The Lampung language texts are the result of Lampung Language description from field work done for two years living in Lampung.

There is an explanation from Teeuw, A. (1996: 119-120) in his article, in subheadings: Back to the Indies: study of the Lampung language there are inform as follow, Study of the Lampung language: Meanwhile the Board of Dutch Bible Society as early as 1862 to send Van der Tuuk to Bali, 1884 study of Javanese. At the request of the colonial Government himself visit the Lampung are, South Sumatra, to study its language. During the final period of his stay in the Netherlands, he had edited a number of Lampung manuscripts, with an introduction on the language 1868. He stayed in South Sumatra for more than a year and he traversed the Lampung area from East to West and from North to South again on foot. We may believe his letters from the period he indulged in this kind of fieldwork in the most literal sense of the world. Several times he mentions of his satisfaction that he is 'whole among the Lampung people' and 'far from the card-playing Indo-European community', which steals so much time and gives no pleasure.

Further explanation by Van der Tuuk, the language of Lampung is divided into two groups, namely Abung dialect adopted by the custom of Pepadun, and the Pubiyan dialect adhered to by the Coastal custom of Ka-Ga-Nga letters derived from Dewa Negari of Sanskrit innovation (Hidayah , Zulyani, 1997: 149). While Komering language is embraced by Komering people who live in Buay Madang, Belitung, Cempaka, Simpang and Martapura Subdistricts, in Ogan Komering Ulu Regency, and in Tanjung Lubuk Subdistrict in Ogan Komering Ilir Regency. The Komering language belongs to the Malay language group with its own dialect which is similar to the language of Coastal Lampung in which community system is heavily influenced by the Regulatory System of the Simbur Cahya Region in the Era of Sultan Badaruddin II of the fourteenth century (Hidayah, Zulyani, 1997: 139), which is necessary observed in this study.

What is interesting to observe in this study is that Malay geographical perspective and Lampung language have a good and close relationship. Historically, Malay speakers and Lampung language in Southern Sumatra in the history of its development until now have its own style that needs to be observed further (AM., Sudirman, 2005: 45). The development of the two languages cannot be separated from the historical development of the past, because in Lampung there has never been a feudal and regular kingdom, which is an indigenous communion established in the 
eighth century in the form of unity, such as Dipuncak Unity, PemanggilanUnity, PugungDibalau Unity, and Darah Putih Unity (Hadikusuma, 1988: 157).

In the last two decades the description of the Lampung usage area is increasingly evident as seen in the Wurm and Hattori maps (1983: 38), and the Foley review in compilations explaining the map of languages in Sumatra, including Lampung, can be considered adequately and able to provide a fundamental understanding of the linguistic situation on the island of Sumatera, although particularly those related to Lampung are somewhat controversial because of statements about the status of isolates --- neutral terms for language, dialect, or subdialek status --- Komering is still incomplete to discuss. This is partly because of the reason Lampung is seen as a group of languages (consisting of Komering and Lampung languages), closely related to kinship. Furthermore, it is said that the Lampung language can be distinguished into two dialects each consisting of two large subdialects (see Wurm and Hattori, 1983: 39).

The reaction that arises from Foley's statement is understandable because the information does not seem to fit True Walker's explanation (1975: 12). According to Walker's notes, Komering's isolate status still needs to be studied further through a qualitative diachronic comparative approach to Komering's isolect to be proved as a closely related language with other dialects of the Lampung Language including both the coastal dialect and the Abung dialect. Although earlier in the quantitative study, it was explained by Walker that Foley's lexical relationship reached 70\% (In principle, as Dyen (1965: 10) describes, that same percentage represents a close relationship between languages (not the interdialect of a language) but Foley's inference has not yet applied the requirements as suggested by Walker, it is recommended that Walker's initial working hypothesis be followed by a qualitative study of the phonological and grammatical aspects of the Komering isolect relationship with other dialects of the Lampung language, to support the hypothesis achieved through that quantitative approach, but the new Foley capturing the initial signal without further consideration directly affirms the unproven Walker hypothesis into a statement that seems to close other possibilities that are not impossible alternatives that are more justifiable. Based on the content of the quantitative study, Walker's claim has actually been preceded by the impression that Dyen acquired through a lexicostatistic study with a limited Swadesh List instruments, which is 100 Swadesh's basic vocabulary.

The result of Dyen's (1965: 18) study shows that the connection of Komering isolect and Lampung language is higher than that stated by Walker, which is $89.1 \%$. The relationship reflects the relationship between two dialects of a language based on 100 lexicon Swadesh. Similarly, to check the association of the Komering isolate with the Menggala dialect (based on the lineage diagram suggested by Walker (1976), the quantification in that relationship is in the hypothesis of $82 \%$--- The diagonal lineage diagram of the Lampung language described by Walker (1976: 1) the existence of two main dialects of Lampung Language. Selection of locations for the sample of this quantitative study of the manuscript, Komering and Menggala showed that there is no significant difference from the quantification which is previously proposed by Dyen. The methodological implications arising from the result of the latter difference Walker suggests that further studies should be done through a qualitative diachronic comparative approach prove that the Komering variation and the Lampung languages are closely related. On the other hand, offer the possibility of a more quantitative 
ardialectological approach comprehensive with dialectometry technique followed by qualitative approach to prove the status of Komering isolect as one of dialects from Lampung Language.

The connection between Komering and Lampung variation is the Lampung language which is separated by the administrative borders of the provincial government, including the outside the province of Lampung which is Komering language, Ranau language in South Sumatra Province, and Cikoneng language in Banten province, West Java. This is as a result of the migration of the population from the past.

This Komering variation is described as follows: The region of South Sumatera Province has nine rivers 'Batang Hari Sembilan', this province is lived by various ethnic group either in languages, in tradition or cultures. The possibility is that there are maybe the nine rivers indicating the pluralism in a variety of cultures since in the beginning until now. Rivers denote an important tool of transformations to relate ethnic groups each other in many areas. This emerges difficulties to communicate between areas and ethnic groups each other. Because of this, limitation lines between among groups, therefore the language of one ethnic group is different from other ethnic groups, for instances language of Komering, a language of Kayu Agung, a language of Pasemah, a language of Musi and so on (Yusdani, Y., 2016).

Based on above description and in accordance with the explanation of Parasta (2012), Komering is a colloquial language that are used by people along the Komering River of South Sumatra. Meanwhile inter-lingual in each village varies elements of sound and vocabulary but this language remains one parent language, Komering language. This lack of regional language understanding and learning will obscure the authenticity of Indonesia that shifted by modern western languages and culture (Subandowo, 2014:625). It is better to learn local languages for cultural preservation and in order to build communication with local communities. On the other hand, this is to raise the potential of local wisdom to the national or international level.

In this paper, qualitative analysis can be seen from the evolution of Lampung and Komering as follows: (1) the same or mirror lexicon group 76,5\%; (2) Different Groups of Lexicon 15,\%\%, and (3) Lexicon Group Loans $8 \%$. While the quantitative study through diachronic linguistic approach done with the purpose of questioning like how far Foley statement proves that Komering variation is closely related to the Lampung language. The same Foley's statement refers to Walker's early study with empirical facts that are found in the field. A quantitative study was conducted to check the truth of Foley's statement. Similarly, it is worth questioning the percentage that is reached $89.1 \%$ of intercultural relation (Komering and Lampung Language). In accordance with the empirical reality of the research instrument expanded by the number of questionnaires reaches a maximum of 200 Swadesh vocabulary draft Language Center (1996) to capture the data in location of usage of Komering variation and Menggala's dialect.

\section{PREVIOUS LITERATURE REVIEW}


According to Dyen (1965), Lampung is part of the Western Austronesian languages 'Hesperonesia'. In the description of the work of Verhoeven in Lampung Language (1955), the result was found that language is related to the bibliography's summary of languages in Sumatra. In addition, the Walker study that has been mentioned above $(1971,1975,1976)$ Lampung has been discussed in detail and in more depth, but the problem of the Komering variation has not been satisfactorily discussed. Much earlier in the study of Van der Tuuk and Van Royen has opined about the Komering variation which is seen as one of the dialects of the Lampung language. This statement needs to be revised because it has undergone many changes over a period of more than a century, mainly due to the influence of user-area shifts or inter-dialect speakers that previously distinguished on dialects $\mathrm{A}$ and $\mathrm{O}$.

This Van der Tuuk view has been reviewed by Teew, A. (1996: 119-120) in his article on how fieldwork has been done in the past as follows: The result of his fieldwork in South Sumatra consisted of some letters and several articles on the Lampung language as well as a draft dictionary, containing some 600 pages, which unfortunately he never found occasion to edit and made ready for publication. In his Lampung studies, we see Van der Tuuk pioneering again, reasserting and applying some of his fundamental views on language study. In a letter from Bogor dated 3 September 1869, soon after his return from South Sumatra, he postulates that for a lexicographer it is essential to study as much as possible the closely related ('sister') languages, not only to explain the relationship between these languages but also in order to be careful in explaining the meaning of the words'. And in his article on the Lampung dialects, he expanded on the necessity 'to know the sound-laws which control (beheerschen) a language, not just to keep oneself free adventurous, but also to connect it easily with its sister languages. If one knows these laws, one no longer wonders about the identity of words which are completely different in sound whereas one also can cast a glance on the earlier life of language. The article makes quite clear again what Van der Tuuk means by 'sound-laws': he pointed out the regular sound correspondences between related languages, in this case between the Lampung dialects and languages such as Sundanese, Batak, Malay, and Javanese. He also makes the methodological essentials distinction between and-word from some of the languages just mentioned, of which there are many words which belong to the common Malay-Polynesian heritage.

In addition, the famous Austronesian Linguist, Dempwolff as Schoroter's guide in his dissertation (1937), discussed the Komering Language as a Komering dialect. The object of the Komering dialect is to analyze the grammar of the language from the standpoint of the language structure. Rianom (1967) prepares a dissertation at IKIP Malang on the analysis of the Lampung language of Komering dialect. From some evidence of the work of previous researchers, it appears that there is recognition of the existence of Komering variation as one of the dialects of Lampung (Cf. Abdurrahman and Yallop, 1979: 11). Likewise, AM., Sudirman $(1999,2006)$ who analyzed the dialect geography of the Lampung language stated a similar way.

In terms of anthropological studies, a number of information from anthropologists has discussed the culture of Lampung and its supporters. The Lampung-Komering relationship has been marked by information on the mobility of past migration, namely, before the end of Sriwijaya rule in the XIV century. At that 
time, the mobility of the Abung migration was the evident because of the migration and assimilation of the local population with the Abung tribe in the Komering area of South Sumatra.

By the local people supporters of Lampung culture, it is believed that there has always been a distinction between Pepadun and Peminggir customary groups. The Lampung group of Pepadun consists of Abung Sewo Mego, Mego Pak Tulangbawang, Buay Lima and Pubian Telu Suku orTribe. Lampung Peminggir consists of Pelinggir Melinting Rajabasa, Peminggir Teluk, Peminggir Skala Brak, Peminggir Semangka, and Pemanggilan Jelma Daya residing in Kayu Agung, Martapura, and Muaradua commonly called the Komering. Furthermore, Komering's anthropological area consists of Komering Ulu and Komering Ilir (Hidayah, Zulyani, 1997: 148; Cf. Sanusi, 1996: 7; and Hadikusuma, 1989: 108).

With regard to Foley's information relating to the explanation of the Ranau, Daya, $(\mathrm{H}) \mathrm{Aji}$ and Lengkayap areas as part of the Lampung region, is actually South Sumatera (1983: 39). It indicates that the three areas are an anthropologically explainable region of Komering. The grouping of cultural support areas based on the tradition explains the synchronous state with the groupings of the Lampung dialects as explained by Van der Tuuk. The inter-group cultural relations according to Foley are more controversial because it refers to the Malay-based region, not in accordance with the actual circumstances in the field. This is because the people classified in the Malay group basically use Malay when communicating with the external spokesperson of the group.

It seems from one side to the point that Foley's neglect of various uncomplicated references such as the lingual records of language varation of the past. This condition is expressed among others Dutch Linguists such as Van der Tuuk, Helfrich, Van Royen who escaped his attention. The implication is that Foley's opinion on Komering isolates status as a separate language or a language closely related to Lampung in the Lampung language group which is still questionable.

Basically, the language of Lampung is spoken by the indigenous people of Southern Sumatra whose spatial region partially enters the province of Lampung and some enters into the South Sumatra Province called Lampung Komering Ulu which has different dialects in Komering Ulu (AM., Sudirman , 1999: 34-35). Furthermore, it should be explained about the evidence of the language that became the focus of the discussion below.

The issue of Komering variation specifically reviewed by Foley invites reactions in this paper for the review that might tend to be ignored by Foley. In Foley illustrations, for example, references have been used to give the impression of countless empirical facts of fieldwork. This is resulted in their statements concerning the various mapping areas of the language in Sumatra, but the explanation is more confusing than explaining the problem.

\section{METHOD}

The study applied in this experiment is descriptive research. The problems of descriptive research phenomenon were laid out, classified, and described by 
researchers as much as possible symptoms that would be perfect on the basis of certain research (Verendbregt, Jacob, 1985: 52). Data collection techniques are obtained from various sources and with various techniques used together to control each other, to complement, and to support each other (Edi Subroto, 1992: 35). The data collection technique is taken mainly from library, namely using written sources, and selected synchronously. Everything is written, and compiled from various literature sources which are limited based on the purpose of the study (Edi Subroto, 1992: 42-43). After the researchers collected the data, the next step was data analysis. "Data handled directly, observed and dissected or aparted of a problem in a certain way" (Sudaryanto, 1993: 6). That is the method of matching, with the technique of appeal (differentiating and equalizing) and equating the principal (Sudaryanto, 1993: 27). Data analysis refers to data filtering, data arranging, data summarizing, data integration, all leading to (conclusion) of research findings (Tarigan, Henry Guntur, 2009: 196).

\section{Discussion of the Study}

In the mapping result, for example, Lampung is stated as part of a group of related languages, namely Komering and Lampung variation. Each has a large dialect and sub-dialect variety. Foley's contribution is based on the limitations of his referenced library, which is based only on Voerhove's (1955). His view whose discussion is somewhat superficial as well as Walker's work on the kinship of Komering and Lampung is still hypothetical (1975). Despite such circumstances, Foley's illustration of the mapping of languages in Sumatra has succeeded in providing a sufficient and useful picture. This condition is to fill the void of information of language situations in Sumatra and surrounding areas as part of the languages of the archipelago West and Austronesia in general.

Furthermore, Foley's information on the status of the Komering variation in this paper is discussed with the assumptions of affordable literature results while devoting attention to (1) the results of previous studies supplemented by more anthropological opinions, (2) the application of analysis empirical data conducted quantitatively which is done more based on the approach of diachronic study.

\section{The Evidence of Komering and Menggala as a Representation Sample of the Quantitative Study of Lampung Variation}

To check the truth of the statement of scholars who have studied the Lampung Language, the experiment was conducted in a quantitative analysis using data Komering at the point of observation of the Village of Gunung Batu Subdistrict Cempaka Komering Ulu Sumsel and Menggala at the observation point Menggala Village Menggala District Tulangbawang Lampung Regency. The two observation areas are located about $350 \mathrm{~km}$ away. Both observation areas were used as samples to capture the data in order to explain the still-questionable status of kinship status. The first observation area was represented by Komering variation and the second observation area was represented in Bengali dialect. Data collection in the field is limited by the use of instruments that aimed at assessing the relationship status 
between Komering and Menggala isolates. As for the above instruments, 200 basic Swadesh vocabularies are used to capture the language data of Komering and Lampung in the field.

After the field data was prepared, the lexicostatistics technique calculated the percentage of cognate between the two areas of observation. This is to determine the kinship of the language in accordance with the applicable procedure. The result data then depicted in both qualitative and quantitative data. The qualitative results are captured on the basis of lexicon instruments of 200 Swadesh Vocabulary, as in the following sample of data; (1) The same or mirror lexicon groups 76.5\%; (2) Different groups of lexicon 15.5\% and (3) The Lexicon Group is a Loan Sound Element $8 \%$.

(1) The same or mirror lexicon groups;

\begin{tabular}{|c|c|c|c|c|c|c|}
\hline \multirow{2}{*}{ No. } & Gloss of & \multicolumn{2}{|c|}{ Komering } & \multicolumn{2}{c|}{ Menggala } & Kinship \\
\cline { 3 - 6 } & Indonesian & Phonetics & Grafem & Phonetis & Grafem & /Geneticly \\
\hline 1 & abu & {$[$ habu] } & $<$ habu $>$ & {$[$ abeu $]$} & $<$ abeu $>$ & + \\
\hline 2 & air & {$[$ way] } & $<$ way $>$ & {$[$ way] } & $<$ way $>$ & + \\
\hline 3 & akar & {$[$ baka?] } & $<$ bakak $>$ & {$[$ waka?] } & $<$ wakak $>$ & + \\
\hline 4 & anjing & {$[$ asu] } & $<$ asu $>$ & {$[$ aseu] } & $<$ aseu $>$ & + \\
\hline 5 & batu & {$[$ batu] } & $<$ batu $>$ & {$[$ batteu] } & $<$ batteu $>$ & + \\
\hline 6 & berenang & {$[$ lanuy] } & $<$ languy $>$ & {$[$ nanuy] } & $<$ nanguy $>$ & + \\
\hline
\end{tabular}

In the data number $1,4,5,6$ above, the lexicons is cognate because of its correspondence in the form of variant sound elements $/ \mathrm{u} / \sim / \mathrm{eu} /$.

(2) Different groups of lexicon

\begin{tabular}{|c|l|c|c|c|c|c|}
\hline \multirow{2}{*}{ No. } & \multirow{2}{*}{$\begin{array}{c}\text { Gloss of } \\
\text { Indonesian }\end{array}$} & \multicolumn{2}{|c|}{ Komering } & \multicolumn{2}{c|}{ Menggala } & Kinship \\
\cline { 3 - 6 } & Phonetics & Grafem & Phonetis & Grafem & /Geneticly \\
\hline 1 & apa & {$[$ api] } & $<$ api $>$ & {$[$ ñou] } & $<$ nyou $>$ & - \\
\hline 2 & baik & {$[$ boti?] } & $<$ botik $>$ & {$[$ waway] } & $<$ waway $>$ & - \\
\hline 3 & bintang & $\begin{array}{c}{[\text { bintuhan, }} \\
\text { bintan] }\end{array}$ & $<$ bintuha $>$ & {$[$ bittan] } & $<$ bittang $>$ & - \\
\hline
\end{tabular}

The data indicating the correspondence of the sound element at data number 35. The result occurs in the closed penultimate position of the sound variant $/ \mathrm{nt}-/ \sim / \mathrm{tt}-$ /; the variant result occurs in homorganic gaminess sound element, homorganic as Malay characteristic, and gaminess as the original character of the sound element of Lampung language.

(3) The Lexicon Group is a Loan Sound Element

\begin{tabular}{|c|l|c|c|c|c|c|}
\hline \multirow{2}{*}{ No. } & Gloss of & \multicolumn{2}{|c|}{ Komering } & \multicolumn{2}{c|}{ Menggala } & Kinship \\
\cline { 3 - 6 } & Indonesian & Phonetics & Grafem & Phonetis & Grafem & /Geneticly \\
\hline 1 & baru & {$[$ ompay $]$} & $<$ ompay $>$ & {$[$ baReu $]$} & $<$ baReu $>$ & $?$ \\
\hline
\end{tabular}




\begin{tabular}{|c|l|c|c|c|c|c|}
\hline 2 & benih & {$[$ bənIh] } & $<$ benih $>$ & {$[$ molan] } & $<$ mulan $>$ & $?$ \\
\hline 3 & pasir & {$[$ honi] } & $<$ honi $>$ & {$[$ pasiR] } & $<$ pasiR $>$ & $?$ \\
\hline
\end{tabular}

Data Lampung language has no element of loan from the Malay language as an innovation, namely /baru/ /baReu/; /pasir/ /pasiR/. While the sound element that survives $\left(\right.$ retention $^{*}$ ) are on the lexicon /ampay/*/ompay/ dan /həni/* $\sim /$ honi/; there has been a reflection of proto language*(/ampay/, and /həni/) to be (/ompay/, and /honi/). This means there has been an inter-language shift.

Whereas quantitatively all lexicons corresponding or corresponding are calculated based on the commonly used dialect metric formulas in the Comparative Historical Study generally, and the Special Studies of Dialectology. The Dialect metric Formula is to calculate the results of the study as follows.

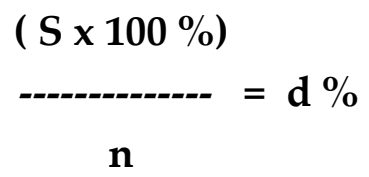

Notes: $\mathrm{S}=$ Corespondency of lexicon as a cognate; $\mathrm{n}=$ The emount of

Lexicon in cognate; $d=$ the result of percentage.

The relation of one observation point to another point in the research area is based on 200 lexicon Swadesh and the above dialectometric formulation. The result can be found that $81 \%$ - upwards is the language difference; $51 \%$ - $80 \%$ dialect differences; 31\% - 50\% subdialect difference; 21\% - 30\% difference speech 'speech'; below 20\% there is no difference (Mahsun, 1995: 118).

Meanwhile, according to Crowley a similar percentage explains the criteria of inter-dialect relationship in a language (1987: 193). Furthermore, Crowley explains in the Lexicostatistic application that it is often indicated by the level of the aspect of 200 Swadesh's vocabulary to the language as the result of the analysis criteria as follows:

\section{Language Status}

Dialects of a language

The language of a sub-family

Subfamilies of a family

Families of a stock

Stocks of a phylum

\section{Percentage of}

\section{Grouping Lexicon}

$$
\begin{aligned}
& 81-100 \% \\
& 55-80 \% \\
& 28-54 \% \\
& 13-27 \% \\
& 05-12 \%
\end{aligned}
$$

The result of the calculation based on the applied dialectometric formula, reached the number $82,16 \%$ which does not show a significant difference from the range of criteria of a previous calculation result of Dyen who used 100 lexicon Swadesh instruments. Thus, the opinion supports the opinion of Dyen that the kinship relationship between Komering isolect with Menggala dialect is the relationship between dialect-dialect of Lampung. If the quantitative diachronic review is completed with a more comprehensive qualitative review then the results will be more 
adequate and reliable. A dialectology study with a quantitative approach using dialectometric techniques such as AM, Sudirman $(1999,2006)$ is expected to answer the necessary questions as a solution to explain Komering's isolect status and its relationship with Lampung Language. In this connection, the dialectological quantitative study of the Komering and Lampung isolate speakers region needs to be specifically re-verified against the observed point of view using 200 (two hundred) Swadesh basic vocabularies, and the invisible qualitative evidence need to be demonstrated.

\section{RESULT OF THE STUDY}

The qualitative study of Komering and Lampung variation at these two points of observation is demonstrated by mutually intelligible mutual understanding data characterized by lexicon similarities, lexicon distinctions and loan lexicons based on a touch of language and culture in the iris 'borderlines'. While the quantitative verification is a review of this lexicostatistics test that used 200 Swadesh Vocabulary with consideration of the original data 'originally' local speakers to avoid the element of absorption of loans from Malay into Komering isolects. In the meantime, the results achieved are not much different from the achievement of the walker worth $82 \%$ (1996). Based on data collecting of Komering isolect and Lampung language after calculated based on Lexicostatistics 200 Swadesh Lexicon, then it obtained a result $82.16 \%$. Further explanation, the classification of Komering as a separate language of a large Lampung language has been disputed by various sources. For example, Foley lists Komering as a distinctive language from Lampung, whereas Fernandez and AM., Sudirman (2002) take issue with this decision and claim that Komering should be listed as a dialect of equal status to the other Lampungic speech varieties. (Hanawalt, Charlie, 2007: 14). Crowley (1987: 193) stated that this similar relationship is called intercultural or interdialect relations. It proves that Komering is related to the languages surrounding it, including the languages of Lampung and Malay (Ogan Malay, Semende Malay, and Minangkabau Malay).

\section{CONCLUSION}

Based on literature review and lexicostatistics about isolect of language above, it can be concluded, that Foley's determination about Komering and Lampung variation is two different variations and each has two big sub-dialects which need to be reviewed in a more recent study. This is because the results achieved by Dyen and the study as supporting evidence in this paper show the opposite result, namely that the Komering variation is one of the dialects in Lampung.

The methodological and theoretical problems underlying this distinction require a further step necessary to examine the object of this study from dialectological and linguistic diachronic angles so that the answers to the problem can be answered. Accordingly, the quantitative study in dialectology field with the wider observation area needs to be performed in addition to the qualitative dialectology study as the initial data of language. On the other hand, a qualitative study with diachronic linguistics approach to the object of research can also be done to observe the 
relationship between the existing dialects in Lampung language with Komering variation. Thus, interdisciplinary studies involving comprehensive dialectology will undoubtedly be useful for finding solutions related to language mapping and more satisfactory explanations.

Some suggestions as inputs in mapping the languages and dialects of the many languages in Indonesia or the archipelago can be put forward as follows. Megaprojects such as those generated based on cooperation with various parties in producing language mappings and dialects Wurm and Hattori versions is a visually attractive mapping with a variety of colors that can amaze the use of various collection of the results of the scattered studies but the results are still far from satisfactory. An explanation of the problem of inter-language or inter-dialect relations is the case that found in the Lampung language.

Whether for more accurate mapping purposes, such as a compilation of linguistic information that complements the mapping needs to be more in line with current realities and developments in language studies. It is necessary to foresee future mapping of a language more adequate than that of Wurm and Hattori (1983). In relation to the matter, the problem of language mapping and dialects undertaken by staking the honor of the name of the Language Center as an Indonesian government agency in the field of linguistic authoritative study can take the lessons from the various weaknesses found in mapping the existing language as well as the monumental work of donation from this Pacific Studies. Language mapping by the Language Center today needs to be more open to managing the results of field data with the help of various parties that are expected to improve the quality of mapping to be generated and in particular for mapping languages in Indonesia. The results are expected to be better than those found in the language maps by Wurm and Hattori. The openness of the Language Center as a Government Institution in an authoritative country in this does matter, especially in relation to the national language mapping of a country can be done by utilizing the expertise of linear and relevant scientists from various universities which are better to ensure success in presenting the great work quality. Therefore, It will be predicted to become increasingly more reliable.

\section{REFERENCE}

Abdurrahman, S., and Yallop. C., (1979). "A Brief Outline of Komering Phonology and Morphology" in Amran Halim (Ed.) Miscellaneus Studies in Indonesian and Language in Indonesian Part IV. Jakarta: Organizing Agency Seri NUSA

AM., Sudirman, (1999). "Geography of Dialects in Lampung Komering Ulu in Southern Sumatra, Tesis". Yogyakarta: Program Pascasarjana UGM

AM., Sudirman dan Inyo Yos Fernandez, (2001). "Status of Komering Isolect in Lampung Language Group" page 31-55 insidePROSIDING NATIONAL SEMINAR LANGUAGES AND AUSTRONESIA II CULTURE is organized by Master Program and Doctoral Linguistics MoU with Master Program of Cultural Studies, PPS Program Udayana Bali, Denpasar February,7 - 82001. 
DENPASAR BALI INDONESIA: Published by the National Seminar Committee on Language and Culture Austronesian II

AM., Sudirman, (2005). Relation of Malay Language and Lampung in Journal of Humanities, Volume 17, Number 1, February 2005 45-54. Yogyakarta: Universitas Gadjah Mada

AM., Sudirman, (2005). Proto Austronesian Reflections on Lampung in LITERA Research, Language, Literature, and Teaching, Volume 4, Number 2, July 2005 pages 221-234. Yogyakarta: FBS (Faculty of Languages and Arts) Yogyakarta State University

AM., Sudirman, (2006). "Geography of the Lampung Language Dialect in Southern Sumatra, Dissertation". Yogyakarta: Graduate School of UGM

Azhar, Iqbal, Nurul, (2011). Critical Times of Cia-Cia. Prosodi, Volume V, Number 2, July 2011, 5 (2)

Crowly, Terry, (1987). An Introduction to Historical Linguistics, Linguistics Series No. 1, Papua New Guinea: University of Papua New Guinea Press University of The North South Pacific

Department of Education and Culture, (1996). Kinship and Mapping Research in Indonesia: Basic Vocabulary Questionnaire and Basic Cultural Word. Jakarta: Depdikbud Language Development and Development Center

Dyen, Isodore, (1965). A Lexicosatistical Classification of the Austronesian Language. Bloomingtoan, Ind.: Indiana University

Foley, W.A., (1983). "Language Atlas of Sumatera" inside Wurm, S.A. and Hattori, Shiro, (eds.) Language Atlas of the Pacific Area. Canberra: The Australian National University

Gunarwan, Asim, (1968). The Lampung Language: Phonemic An Analysis and its Application to Teaching English, Skripsi. Malang: IKIP Malang

Hadikusuma, Hilman, (1989). Communities and Indigenous Cultures of Lampung. Bandung: CV Mandar Maju Publisher

Hidayah, Zulyani, (1997). Encyclopedia: Tribe of Nations in Indonesia. Jakarta: PT Pusaka LP3ES Indonesia

Hanawat, Charlie, (2007). Bitter or Sweet? The Vital role of sociolingustic survey in Lampungic dialectology. Studies in Philipines Language and Cultures, 16, 1140

Parasta, J. T., (2012). Penguraian Kata pada Kalimat bahasa Komering Rasuan Berdasarkan kaidah bahasa Menggunakan teori automata. Journal Research Computer Science \& Application, 1(1)

Royen, JW Van, (1930). Nota over de Lampoengsche Merga's Landsdrukkrij Weltevraden. Batavia: TBG Bruining \& Wijt 
Schroter, Richard, (1937). "Versuch einer gfamaatichen Auslegung des KomeringDialektes der Lampung-Sprache". Hamburg: Dissertation zur Erlangung der Doktorwurde der Philoshischen Fakultat der Hansischen Universitat

Sanusi, A. Effendi, (1996). Literature Oral Lampung Abung Dialect. Bandar Lampung: Published of Gunung Pesagi.

Subandowo, D. (2014). Strategi Kesopanan Berbahasa terhadap Kemampuan Tindak Tutur Mahasiswa PBI UM Metro. Etnoreflika: Jurnal FIB Universitas Halu Oleo, 3(1), 622-631.

Subroto, Edi, (1992). Structural Linguistic Research Methods. Surakarta-Solo: Sebelas Maret University Press

Sudaryanto, (1993). Methods and Miscellaneous Language Analysis Techniques:Introduction to the Linguistic Research of the Cultural Forum. Yogyakarta: Duta Wacana University Press

Tarigan, Henry Guntur, (2009). Basic Principles of Research Methods of Language Teaching and Learning. Bandung: Publisher Angkasa Bandung

Teew, A., (1996). Van der Tuuk as Lexicographer. In: Archipel, Volume 51, 1996, pp. 113-133; doi: 10.3406/arch, 1996.1097 http://www.persee.fr/doc/ arch_00448613_1996_num_51_1_1097 Document genere le 17/03/2016

Tuuk, HN Van der, (1868). "Lis manuscripts en possession de M. le Baron Sloet van de Beele" in Indische Taal-, Land- En Vokkenkunde Del 12. Batavia: Lange \& Co's Hage, M. Nijhoff

Tuuk, HN Van der, (1869). "Brieven van HN Van der Tuuk Betreffende Het Lampongsch" in Indische Tall-, Land- En Vokkernkunde Del 19. Batavia: W. Bruining \& Co's Hage, M. Nijhoff

Tuuk, HN Van der, (1872). "'t Lampongsch En Zijne Tongvallen" in Indische Taal-, Land- En Vokkenkunde Del 18. Batavia: W. Bruining \& Co 's Hage, M. Nijhoff

Verendbregt, Jacob, (1985). Pengantar Metodologi untuk Ilmu-Ilmu Empiris. Jakarta: Penerbit ILDEP dan PT Gramedia

Voorhoeve, P., (1955). Critical Survey of Studies on the Language of Sumatra. The Hagu: M. Nijhoff

Walker, Dale, F., (1973). "A Sketch of the Lampung Language: The Pesisir Dialect of Way Lima, Thesis". USA: Cornell University

Walker, Dale, F., (1975). "Lexical Study of Lampung Dialect" dalam Verhaar JWM (ed.) Miscellaneus Studies in Indonesian and Language in Indonesia Part I. Jakarta: Badan Penyelenggaa Seri NUSA

Walker, Dale, F., (1976). "A Grammar of the Lampung Language: The Pesisir Dialect of Way Lima". Jakarta: Badan Penyelenggara Seri NUSA

Yusdani, Y. (2016). The Book Of Simbur Cahaya: The Receptive Theory Point Of View.Millah: Journal of Religious Studies, 3(2), 235-254. 